(i) (i) (i) (i) (i) (i) Di(i) (3) (3) (3) (3) (i) (3) ISSN: 2598-7607 e-ISSN: 2622-223X

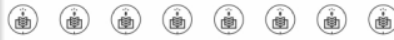

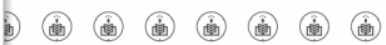

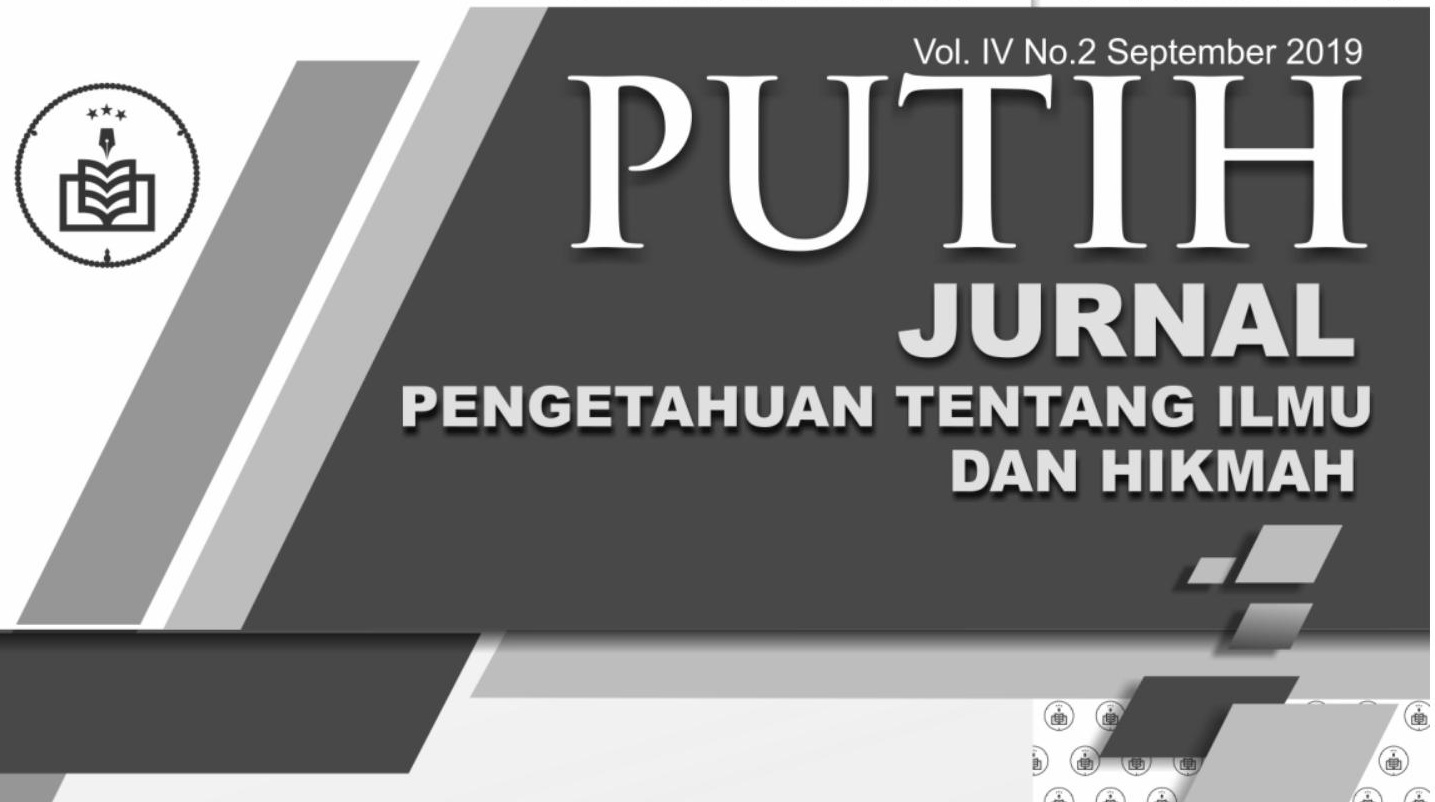

- PRINSIP-PRINSIP BUDAYA SEBAGAI SUMBER HUKUM ISLAM FathurRozi

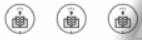

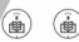
i

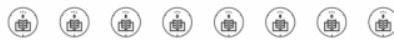

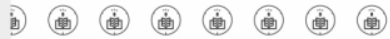

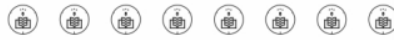

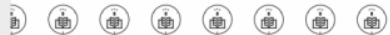

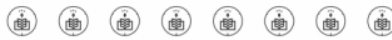

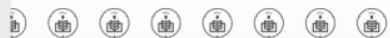

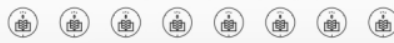

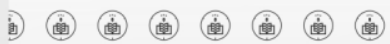

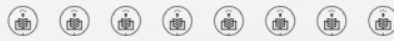

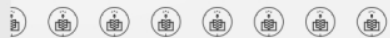

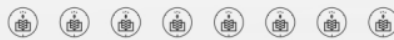

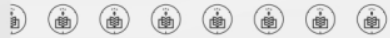

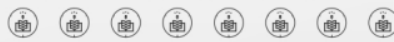

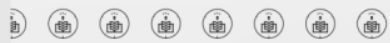

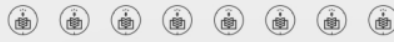

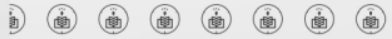

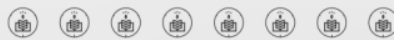
diterbitkan :

MA'HAD ALY

PONDOK PESANTREN ASSALAFI AL FITHRAH Surabaya

ib) (iii) (iii) (ii) (ii) (iii) (ii) (ii)

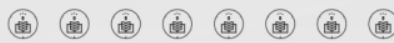
ib) (ii) (ii) (ii) (i) (i) (ii) (ii)

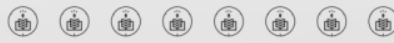
ii) (ii) (ii) (ii) (ii) (ii) (ii) (ii)

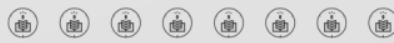

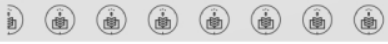




\section{Redaktur PUTIH \\ JURNAL PENGETAHUAN TENTANG ILMU DAN HIKMAH}

Ijin terbit

SK. Mudir Ma'had Aly No. 18/MAy-PAF/II/2018/SK

PEMBINA

Muhammad Musyafa'

Abdur Rosyid

Ahmad Syathori

PENGARAH

Fathur Rozi

PIMPINAN REDAKSI

Fathul Haris

DEWAN EDITOR

Achmad Imam Bashori

\section{ANGGOTA \\ Mustaqim \\ Samsul Arifin \\ Abdul Hadi}

Alamat Penyunting dan Surat Menyurat :

J1. Kedinding Lor 99 Surabaya
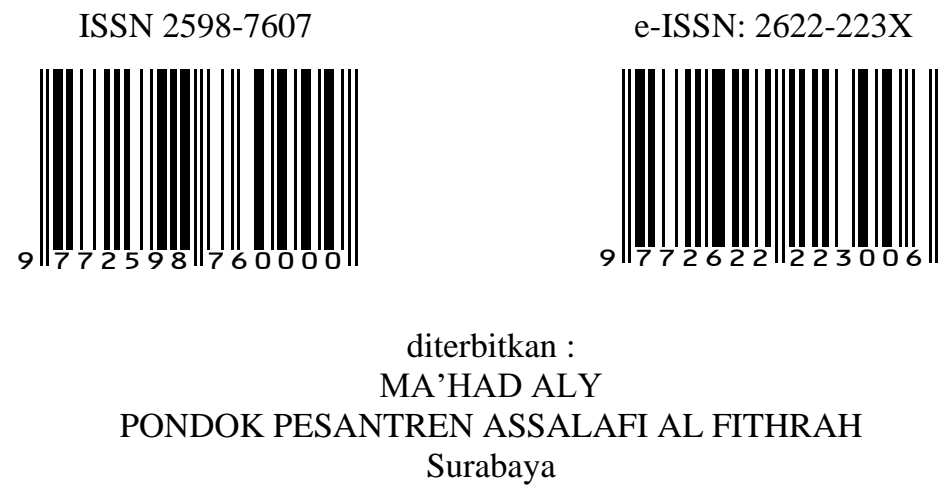


\section{$\underline{\text { Daftar Isi }}$}

- Daftar Isi

- Pedoman Transliterasi

- PRINSIP-PRINSIP BUDAYA SEBAGAI SUMBER HUKUM ISLAM

FathurRozi

- Jumlah Anak Ideal dalam Perspektif Hadis Muzamil

- Mengenal Tafsir Latā'if al-Isharāt Karya al-Qushayrī (Kerangka Metodologis dan Kecenderungan Ideologis) Kusroni

- MAHKOTA SINGGASANA DALAM ISTANA SHUFIYAH

Kajian Ruang Lingkup Maqomat Dan Ahwal (Pangkat, Derajat dan Kedudukan Para Shufi Di Sisi Allah Swt.)

Ahmad Syatori

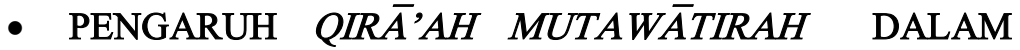
HUKUM FIQH

Abu Sari

- $A L-A S \overline{S I}:$ PENAFSIRAN AL QURAN DENGAN BAHASA ARAB

Fathul Haris 


\section{PEDOMAN TRANSLITERASI}

Berikut ini adalah skema transliterasi Arab-Indonesia yang ditetapkan dalam penulisan jurnal ini:

\begin{tabular}{|c|c|c|c|c|}
\hline $\mathrm{NO}$ & ARAB & INDONESIA & ARAB & INDONESIA \\
\hline 1 & 1 & 6 & $b$ & $\mathrm{t}$ \\
\hline 2 & ب & B & ظ & $\mathrm{Z}$ \\
\hline 3 & ت & $\mathrm{T}$ & $\varepsilon$ & ' \\
\hline 4 & ث & Th & $\dot{\varepsilon}$ & gh \\
\hline 5 & ج & $\mathrm{J}$ & ف & $\mathrm{F}$ \\
\hline 6 & $\tau$ & h & ق & Q \\
\hline 7 & $\dot{\tau}$ & $\mathrm{Kh}$ & s) & $\mathrm{K}$ \\
\hline 8 & د & D & J & $\mathrm{L}$ \\
\hline 9 & ذ & $\mathrm{Dh}$ & 5 & $\mathrm{M}$ \\
\hline 10 & $\jmath$ & $\mathrm{R}$ & ن & $\mathrm{N}$ \\
\hline 11 & j & $\mathrm{Z}$ & 9 & W \\
\hline 12 & س س & $\mathrm{S}$ & هـ & $\mathrm{H}$ \\
\hline 13 & ش & Sh & $s$ & , \\
\hline 14 & ص & $\mathrm{s}$ & ي & $\mathrm{y}$ \\
\hline 15 & ض & d & & \\
\hline
\end{tabular}

Untuk menunjukkan bunyi hidup panjang (madd) dengan cara menuliskan coretan horizontal di atas huruf $\bar{a}, \bar{i}$ dan $\bar{u}$ (أو، إِئ $\left.1 i_{6}\right)$. 


\title{
Jumlah Anak Ideal dalam Perspektif Hadis
}

\author{
Oleh \\ Muzamil $^{1}$ \\ STAI Taswirul Afkar Surabaya \\ Muzammilhasan11@gmail.com
}

\section{Abstraksi :}

Hadis sebagai sumber ajaran Islam mempunyai pengaruh yang sangat besar pada prilaku umat Islam dalam berbagai bidang kehidupan. Di antaranya pemahaman dan perilaku masyarakat dalam kehidupan keluarga. Di antara hadis yang banyak dijadikan alasan untuk membenarkan sebuah prilaku untuk memperbanyak keturunan adalah hadis Nabi Muhammad saw. Namun, di sisi lain pemerintah Indonesia memiliki kebijakan mengikuti program KB (Keluarga Berencana) dengan selogan "Dua anak cukup".

Rumusan dari latar belakang tersebut ada dua. Pertama, bagaimana kualitas hadis tersebut. Kedua, berapa jumlah anak yang ideal menurut hadis tersebut, hadis terkait dan pertimbangan lain.

Penelitian ini bercorak penelitian kepustakaan (library reseacrh). Adapun sifat penelitian ini adalah kualitatif. Sedangkan metode yang digunakan dalam menganalisis pesan hadis tersebut adalah metode kritik dan pemahaman hadis yang mencakup dua hal, tekstual dan kontekstual.

Dengan menerapkan metode tersebut, penulis berkesimpulan bahwa hadis tersebut berkualitas sahih dari sisi sanad dan matan. Dari sisi sanad, hadis ini memiliki lima jalur dari level sahabat sampai kolektornya. Dalam ilmu Mustalah al Hadith, Hadis tersebut termasuk dalam kategori Hadis Ahad yang secara spesifik disebut Hadis Masyhur. Adapun jumlah anak yang ideal adalah tiga dengan argumen a) Dalam tata bahasa Arab, kata banyak atau jama' merujuk pada angka tiga. b). Untuk mempertahankan Peradaban dan

\footnotetext{
${ }^{1}$ Dosen Sekolah tinggi Agama Islam Taswirul Afkar Surabaya
} 
kebudayaan yang sangat terkait dengan keberlangsungan generasinya. c) Menurut teori sibling rivalry, Stabilitas perkembangan psikologis anak lebih baik jika jumlah anak lebih dari dua.

Kata kunci: Jumlah anak, ideal, Hadis

\section{Pendahuluan}

Banyak pasangan keluarga muda di Indonesia saat ini memiliki pandangan bahwa jumlah anak itu cukup dua saja. Satu anak sangat minim dan tiga anak terlalu banyak. Di antara alasannya adalah kesulitan mengurusnya, berat membiayai hidupnya, takut tak bisa menyekolahkannya, khawatir tidak bisa mendidiknya karena kesibukan kerja dan lain-lain.

Salah satu teman istri yang biasa dipanggil Mama Rafa (30 tahun), ibu dua anak yang masih balita mengungkapkan keluhannya: "Udah ah, nggak mau nambah anak lagi, ngurus dua anak saja repot banget, berantem melulu, nggak kebayang kalau tambah lagi, bisa stres!”.

Lain lagi dengan Ibu Fahri (33 tahun), dua anaknya masih kecil, tapi Ibu Fahri masih berharap punya bayi lagi. "Bisa untuk hiburan", demikian tuturnya. Namun, suami Ibu Fahri tak sepakat. Tak jelas kenapa, tetapi Ibu Fahri menduga suaminya yang Pengusaha mungkin mempertimbangkan supaya bisa optimal dalam mendidik kedua anaknya.

Kondisi tersebut berbeda dengan kondisi yang dialami orang tua di era tahun 60/70-an. Mereka memegang pesan yang diwariskan 
orang tua sebelumnya. "Banyak anak banyak rezeki!", begitu kata orang tua zaman dulu. Itu sebabnya mereka tidak pernah takut punya anak banyak, tidak khawatir tidak dapat memberi makan, dan tidak pula mengeluh merasa direpotkan oleh anak-anaknya. Bahkan, keikhlasannya menerima anugerah anak banyak menyebabkan tangannya tidak pernah berhenti mendo'akan anak-anaknya agar kelak menjadi manusia yang berguna bagi agama, bangsa dan negaranya.

Perbedaan persepsi, keterampilan mengurus dan mendidik anak, serta keyakinan terhadap jaminan rezeki Allah kepada setiap anak, menjadi kunci bagi orang tua memandang bahwa punya anak banyak akan merepotkan atau tidak. Dari ketiga faktor tersebut ada orang tua yang secara sadar atau tidak memandang bahwa punya anak itu adalah harapan sekaligus kekhawatiran. Namun, Pemahaman agama yang benar akan membimbing kita untuk memandang bahwa anak adalah anugerah, amanah dan aset masa depan.

Sebagai umat beragama, dalam menyikapi hal tersebut seharusnya kita menjadikan Alquran, Hadis dan pandangan para cendikiawan muslim sebagai pertimbangan dalam memahami hal tersebut.

Sebagaimana firman Allah dalam surat al Nisa' 59

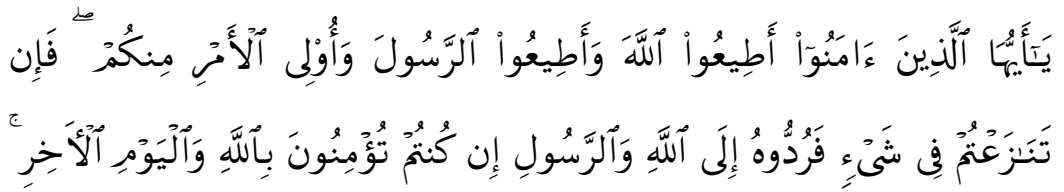




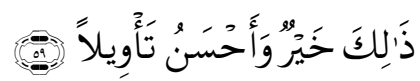

Hai orang-orang yang beriman, taatilah Allah dan taatilah Rasul (Nya), dan ulil amri di antara kamu. kemudian jika kamu berlainan Pendapat tentang sesuatu, Maka kembalikanlah ia kepada Allah (Alquran) dan Rasul (sunnahnya), jika kamu benar-benar beriman kepada Allah dan hari kemudian. yang demikian itu lebih utama (bagimu) dan lebih baik akibatnya.

Ayat tersebut menjadi sebuah landasan bagi kita sebagai umat Islam untuk senantiasa menjadikan Alquran, Hadis dan fatwa para Ulama -selama tidak bertentangan dengan Allah dan RasulNyasebagai acuan dalam melangkah.

Dalam artikel ini, penulis akan mengkaji jumlah anak yang ideal tersebut melalui Sabda Rasulullah tentang anjuran untuk memperbanyak keturunan (baca: anak). Mengingat adanya pemahaman yang beragam di tengah masyarakat. Satu kelompok memahami bahwa banyak anak akan mengundang banyaknya rezeki dan menjadi sebuah tindakan mengikuti perintah Nabi Muhammad. Adapun kelompok yang lain (baca: Pemerintah) menganjurkan untuk membatasi jumlah anak dengan argumentasi lebih memprioritaskan kualitas anak.

Tingginya laju pertumbuhan penduduk Indonesia tersebut dapat dilihat dari statistik yang dikeluarkan oleh pusat statistik mulai tahun 1971-2010. Pada tahun 1971, penduduk berjumlah 119, 208, 229, tahun 1980 berjumlah 147, 490, 298, tahun 1990 berjumlah 179, 378, 946, tahun 1995 berjumlah 194, 754, 808, tahun 2000 
berjumlah 206, 264, 595, dan tahun 2010 berjumlah 237, 641, 326. ${ }^{1}$

Sudibyo Alimoeso, sekertaris Badan Kependudukan dan Keluarga Berencana Nasional (BKKBN) menyatakan bahwa penduduk Indonesia pada tahun 2011 akan mencapai 241 juta jiwa. $^{2}$ Prediksi tersebut berdasarkan hasil sensus penduduk pada tahun 2010 tentang jumlah penduduk Indonesia yang mencapai 237,6 juta jiwa.

Di dalam ilmu sosiologi disebutkan bahwa salah satu masalah sosial adalah masalah kependudukan karena pembangunan ekonomi dan peningkatan kesejahteraan rakyat harus disertai dengan pengaturan pertumbuhan jumlah penduduk melalui program keluarga berencana dan transmigrasi. ${ }^{3}$

Di samping tingginya laju pertumbuhan penduduk tersebut, di kalangan Intelektual Islam, sikap terhadap program keluarga berencana selalu dilihat dari sisi hukum. Menurut kelompok yang kontra bahwa program tersebut bertentangan dengan hadis Nabi yang menganjurkan untuk memperbanyak keturunan. ${ }^{4}$ Di anatar tokoh yang pro terhadap program keluarga berenacana adalah Masjfuk Zuhdi yang sangat menganjurkan kepada masyarakat untuk

\footnotetext{
${ }^{1} \mathrm{http}: / / w w w . b p s . g o . i d /(19$ Desember 2011).

${ }^{2}$ http://www.republika.co.id/berita/nasional/umum/11/07/05/lnua4pprediksi-bkkbn-2011-penduduk-indonesia-241-juta-jiwa,dipublikasikan pada tgl. 5 Juli 2011.

${ }^{3}$ Soerjono soekanto, Sosiologi suatu pengantar (Jakarta: Raja Grafindo Persada, 2007), 338-339.

${ }^{4}$ Muhammad Ibn Jamil Zainu, Kaifa Nurabbi Aulādana (Tt: t.th), 33-34 dan www. Pesantrenonline. Net (18 Desember 2011).
} 
melaksanakan program keluarga berencana ${ }^{1}$, Majlis Ulama Indonesia yang juga melihat bahwa substansi ajaran Islam terkait dengan kependudukan adalah perintah untuk melahirkan keturunan yang berkualitas ${ }^{2}$.

Dari data dan uraian tersebut, kajian tentang hadis yang menganjurkan untuk memeperbanyak keturunan dalam konteks kekinian (baca: Indonesia) menjadi sangat urgen sehingga keabsahan hadis tersebut bisa dipastikan dan nantinya akan didapatkan pemahaman substantif dan proporsional yang sesuai dengan semangat disabdakannya hadis tersebut.

Penulis akan membuat dua rumusan masalah sebagai poin pembahasan. Pertama, bagaimana kualitas hadis tersebut dan dalam kajian ilmu mustalah, hadis tersebut termasuk hadis apa, Ahad atau mutawatir. Kedua, berapa jumlah anak yang ideal menurut hadis tersebut dan pertimbangan psiologi anak

\section{Pembahasan}

1. Takhrīj Hadis

Terminologi takhrij yang relevan dengan konteks penulisan ini adalah identifikasi letak asal hadis pada sumbernya, yakni berbagai kitab yang di dalamnya dikemukakan hadis terkait secara lengkap dengan sanadnya masing-masing, kemudian guna

\footnotetext{
${ }^{1}$ Masjfuk Zuhdi, Masail Fiqhiyah (Jakarta: PT. Gunung Agung, 1997), 5464.

2 http://www.mui.or.id dan Majlis Ulama Indonesia, Kumpulan fatwa Majelis Ulama Indonesia (Jakarta: Pustaka Panji Mas, 1984), 155-171.
} 
kepentingan penulisan maka dijelaskan kualitas hadis yang bersangkutan. Hal tersebut sesuai dengan pendapat M. Syuhudi Ismail yang dikutip dari berbagai sumber ${ }^{1}$.

Kegiatan takhrij hadis membutuhkan metode yang sesuai. Dalam konteks penulisan hadis tentang perintah memperbanyak ketrurunan tersebut, menurut hemat penulis, metode yang akan digunakan ada dua macam, yaitu metode takhrij melalui lafal-lafal yang terdapat dalam hadis atau biasa disebut dengan istilah takhrij hadith bi al lafdh ${ }^{2}$. Kedua metode takhrij melalui tema hadis (tematik) atau takhrij hadith bi al Maudhu.' ${ }^{3}$ Untuk metode yang pertama, penulis menggunakan al Mu'jam al mufahras li al fä al Hadith al Nabawỉ karya tim yang diketuai oleh AJ. Winsinck. Adapun metode yang kedua, penulis menggunakan Miftāh Kunūz al Sunnah karya tim yang diketuai oleh AJ. Winsinck (w. 1939 M.) yang diterjemah ke dalam bahasa Arab oleh Fūad 'Abdul Bāqìi.

Identifikasi sumber hadis tersebut dalam kitab-kitab hadis dengan menggunakan metode tematik hanya menemukan satu hadis yang diriwayatkan oleh Abi Dāud di topik nikah dengan sub topik menikahi wanita yang mandul. ${ }^{4}$

${ }^{1}$ M. Syuhudi Ismail, Metodologi Penulisan Hadis Nabi (Jakarta: Bulan Bintang, 1992), 42-43.

${ }^{2}$ M. Syuhudi Ismail, Cara Peraktis Mencari Hadis (Jakarta: Bulan Bintang, 1991), 17.

${ }^{3}$ M. Syuhudi Ismail, Metodologi Penulisan Hadis Nabi, 49.

4 Aj. Winsinck, Miftah Kunüz al Sunnah (Lahore: Suhail Akademi, 1971 M), 508 . 
Adapun Takhrij dengan metode lafaz dengan menggunakan kata kunci nakaḥa, ${ }^{1}$ Zawaja, ${ }^{2}$ wadud, ${ }^{3}$ dan walud, ${ }^{4}$ menemukan teks hadis di berbagai kitab hadis sebagai berikut:

a. Sunan Ibn Mājah, (2) kitab al Nikāh

b. Ahmad Ibn Hambal, (3) juz 2 hal 172

c. Sunan Abi Daud, kitab al Nikah juz 3

d. Sunan al Nasāi, Kitab al Nikāḥ, juz 11

Dengan demikian, hadis-hadis tentang perintah memperbanyak keturunan yang berhasil dikumpulkan dengan menggunakan dua metode tersebut berjumlah 7 hadis dari 4 kitab hadis.

Setelah diketahui posisi hadis tersebut dalam kitab-kitab hadis, berikut akan ditampilkan redaksi hadis secara lengkap sanad dan matannya.

Redaksi dan sanad hadis secara lengkap ditemukan di beberapa kitab hadis dengan perincian sebegai berikut:

a. Sunan Abi Dāwud ${ }^{5}$

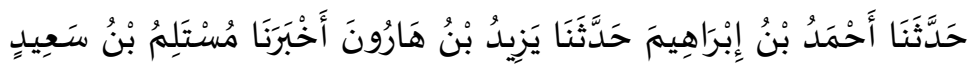

${ }^{1}$ Aj. Winsinck, Concordence et indices de la Tradition Mussulmane, diterjemahkan oleh Muhammad Fu' ad 'Abdul Bāqi dengan judul Mu'jam al Mufahras li Alfăz al Hadith al Nabawīi, juz VIII (leiden: EJ. Brill, 1936 M), 552.

${ }^{2}$ Ibid, vol 2, 358.

${ }^{3}$ Ibid, vol 7, 167.

${ }^{4}$ Ibid, vol 7, hal 319 .

${ }^{5}$ Sulaiman Ibn Asy'as al Sijistani, Sunan Abi Dāud, Vol II (Beirut: Dār Ibn Ḥazm, 1997), 373. 


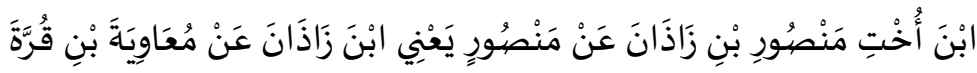

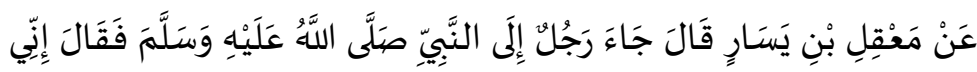

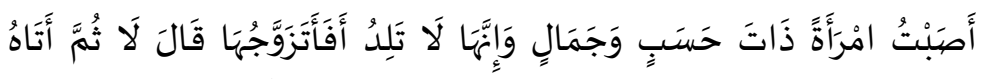

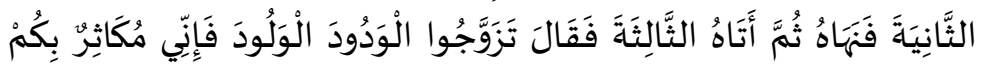

Seorang laki-laki datang kepada Nabi Muhammad saw seraya bertanya tentang maksud dan rencananya untuk menikahi seorang wanita yang cantik dan memiliki kedudukan namun tidak dapat hamil, lalu Nabi berkata "Jangan". Kamudia orang tersebut datang lagi kepada Nabi sambil melontarkan pertanyaan yang sama sampai tiga kali, namun Nabi tetap melarangnya lalu bersabda "nikahilah wanita yang penuh dengan kasih sayang dan berpotensi untuk mempunyai anak karena sesungguhnya saya akan bersaing dalam hal banyaknya jumlah umat dengan umat-umat yang lain ”.

b. Sunan al Nasai ${ }^{1}$

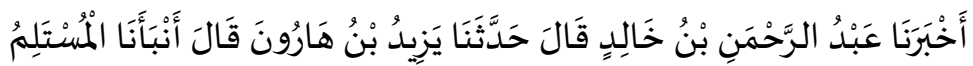

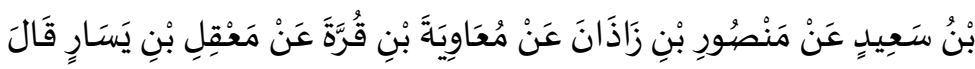

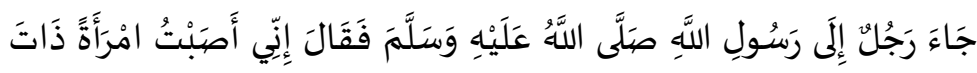

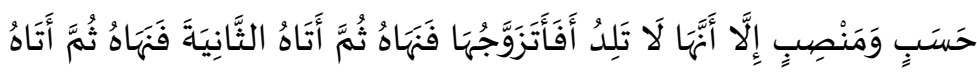

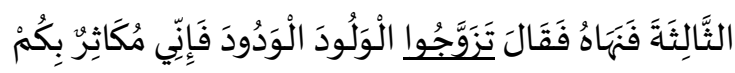

Seorang laki-laki datang kepada Nabi Muhammad saw seraya bertanya tentang maksud dan rencananya untuk menikahi seorang wanita yang cantik dan memiliki kedudukan namun tidak dapat hamil, lalu Nabi berkata "Jangan". Kamudia orang tersebut datang lagi kepada Nabi sambil melontarkan pertanyaan yang sama sampai tiga kali, namun Nabi tetap

${ }^{1}$ Ahmad Ibn Syuaib al Nasāì, Sunan al NasāI, Vol III (Beirut: Dār al Ma'rifah, t.th) 373-374. 
melarangnya lalu bersabda "nikahilah wanita yang berpotensi untuk mempunyai anak dan penuh kasih sayang karena sesungguhnya saya akan bersaing dalam hal banyaknya jumlah umat dengan umat-umat yang lain".

c. Sunan Ibn Mājah ${ }^{1}$

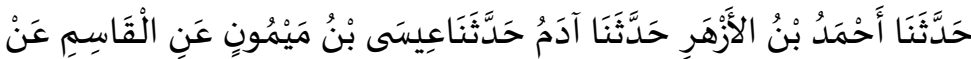

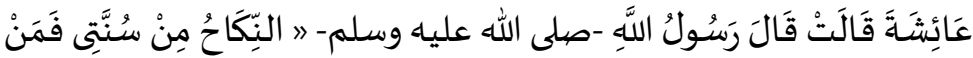

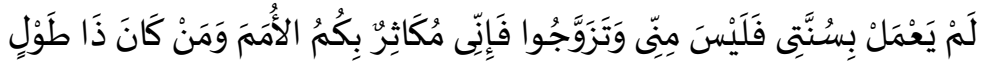

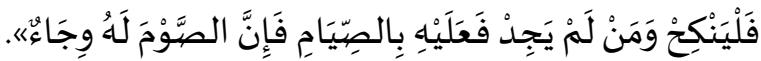

Pernikahan adalah bagian dari sunnahku. Barang siapa yang enggan dengan sunnahku maka dia tidak termasuk ke dalam golonganku. Menikahlah kalian karena sesungguhnya saya bersaing dalam hal memperbanyak jumlah umat dengan umatumat yang lain dan barang siapa memiliki kemampuan, maka menikahlah dan barang siapa tidak mampu, maka hendaklah mengerjakan puasa karena sesungguhnya puasa dapat menekan nafsu syahwat.

d. Sunan Ibn Mājah²

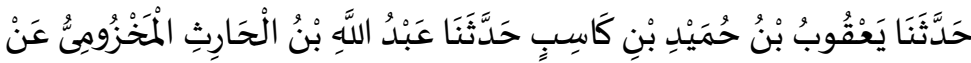

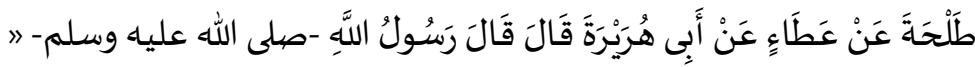

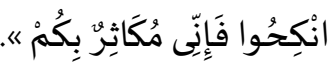

Menikahlah kalian karena sesungguh saya bersaing dalam hal memperbanyak jumlah umat dengan umat-umat yang lain.

e. Musnad Ahmad ${ }^{1}$

${ }^{1}$ Muhammad Ibn Yazìd al Qazwaini, Sunan Ibn Mājah, Vol II (Beirut: Dār al Ma'rifah, T.Th), 406-407.

${ }^{2}$ Ibid, Vol II, 417-418. 


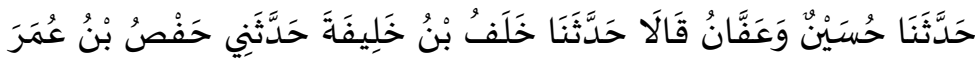

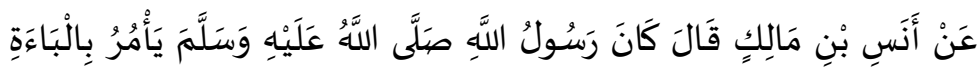

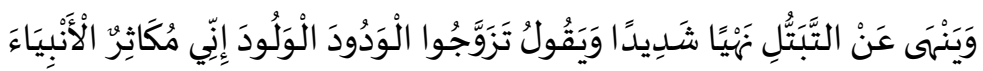

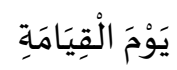

Rasulullah memerintahkan untuk menikah dan sangat melarang untuk membujang dan bersabda "menikahlah kalian dengan wanita yang penuh kasih sayang dan berpotensi untuk memiliki banyak anak karena sesungguhnya pada hari kiamat, saya akan bersaing dalam hal jumlah umat dengan para Nabi "

f. Musnad Aḥmad ${ }^{2}$

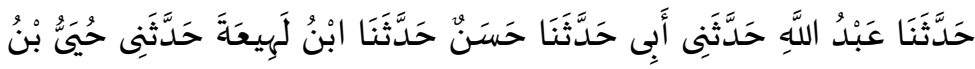

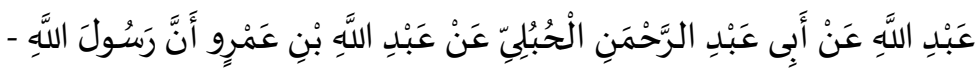

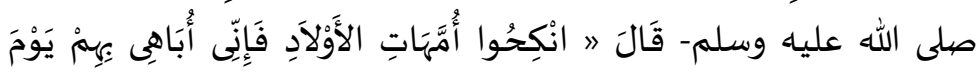

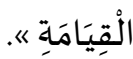

Menikahlah dengan Ummahāt al Aulād, karena sesungguhnya aku akan membanggakan mereka di hari kiamat.

g. Musnad Ahmad ${ }^{3}$

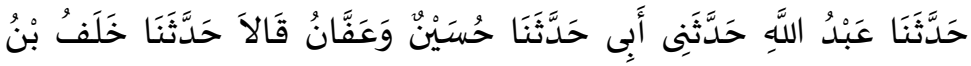

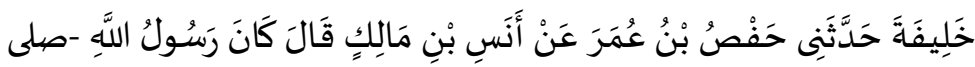

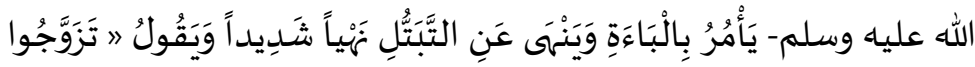

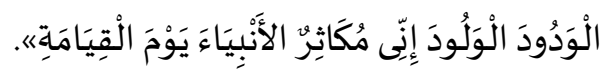

Rasulullah memerintahkan untuk menikah dan sangat melarang untuk membujang dan bersabda "Menikahlah

1 Ahmad Ibn Hambal, Musnad Ahmad Ibn Hambal; Musnad Anas Ibn Malik, vol 19 (Beirut: Muassasah al Risālah, 1997)

${ }^{2}$ Ibid, Musnad 'Abdullah Ibn 'Amr, Vol XI.

${ }^{3}$ Ibid, Musnad Anas Ibn Malik, vol. xix. 
dengan wanita yang penuh kasih sayang dan berpotensi untuk memiliki banyak anak karena sesungguhnya pada hari kiamat, saya akan bersaing dalam hal jumlah umat dengan para Nabi”.

2. I'tibār dan Skema Sanad Hadis

Setelah mencermati berbagai sanad yang dimiliki oleh Hadis tentang perintah untuk memperbanyak keturunan tersebut, penulis berkesimpulan bahwa hadis tersebut memiliki lima Musyāhid (Anas Ibn Mālik, Aisyah, Abdullah Ibn Amr, dan Abu Hurairah) dan lima mutābi' (hafs Ibn Umar, al Qāsim, Abdurrahman al Hubuli, A'țō').

Setelah melakukan I'tibar, berikut akan ditampilkan Skema sanad hadis riwayat Abī Dāud tentang perintah untuk memperbanyak keturunan..

\section{Skema Sanad Hadis Riwyat Abī Dāud Tentang Perintah Memperbanyak Keturunan}

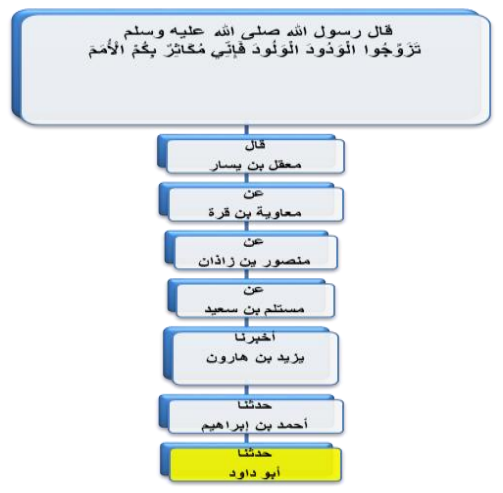

Mata rantai periwayatan hadis tersebut yang berupa 
Ma'qal Ibn Yasār ${ }^{1}$, Mua wiyah Ibn Qurrah², Manșūr Ibn Zādān ${ }^{3}$, Mustalim Ibn Saīd ${ }^{4}$, Yazìd Ibn Hārūn ${ }^{5}$, Aḥmad Ibn Ibrahīm ${ }^{6}$ dan Abū Dāud ${ }^{7}$ memenuhi persyaratan untuk mengantarkan hadis tersebut sebagai hadis sahih. Untuk mengetahui biografi dan penilaian para kritikus hadis terhadap para periwayat hadis tersebut, silahkan buka kembali link referensi di catatan kaki.

Jika dikorelasikan dengan penelitian tentang lambang periwayatan yang digunakan oleh periwayat pertama, kepribadian dan kredibilitas para periwayat hadis tentang perintah untuk memperbanyak keturunan dari jalur riwayat Abu Dāud dan ketersambungan informasi dari periwayat pertama (baca : Ma'qal Ibn Yasār) sampai periwayat terakhir (baca: Abū Dāud), maka dapat disimpulkan bahwa hadis tersebut marfu' dan kualitas sanadnya sahih.

3. Jumlah Anak yang Ideal

Secara ekplisit, Nabi Muhammad saw, tidak menyebutkan jumlah anak yang beliau inginkan pada umatnya. Dalam hadis yang diteliti tersebut, Nabi Muhammad saw. hanya menyatakan bahwa beliau akan berbangga-bangga

1 'Muslim Ibn Hajjaj, Șahịh Muslim, Vol IV (Riyaḍ: Dār al Ṭayyibah, 2006), 1968.

${ }^{2}$ Ibn Hajar al A'sqalani, Tahzīb al Tahzỉb, vol.10, 217.

${ }^{3}$ Ibn Hajar al A'sqalani, Tahzỉb al Tahzib, vol.10, 307.

${ }^{4}$ Ibn Ḥajar al A'sqalani, Tahzỉb al Tahzib, vol 10, 104.

${ }^{5}$ Ibn Hajar al A'sqalani, Tahzỉb al Tahzib, vol.11, 368.

${ }^{6}$ Ibn Ḥajar al A'sqalani, Tahzỉb al Tahzỉb, vol.11, 246.

7 Kamil Muhammad Muhammad Uwaidah, A'lamu al-Fuqaha' wa alMuhaddisin: Abu Daud, (Beirut: Dār al-Kutub al-Ilmiah, 1996), 3 
dengan Para Nabi terdahulu dalam hal jumlah umat. Sepintas, jika kita hanya melihat informasi Nabi tersebut, maka kita akan segera menyimpulan bahwa Nabi bangga dengan umat Islam yang memiliki banyak anak dan bahkan semakin banyak anak yang kita miliki maka potensi kebanggaan Nabi kepada kita akan semakin besar.

Dalam memahami pesan Nabi tersebut, sebaiknya kita juga melihat hadis lain yang terkait dengan regenerasi, kondisi masa kini dan kondisi psikologis anak dalam sebuah keluarga, apakah jumlah anak berpengaruh terhadap perkembangan psikologi anak atau tidak?. Tiga pertimbangan tersebut, menurut hemat penulis akan dapat mengantarkan kita, sebagai umat islam yang ingin dibanggakan oleh Junjungan kita, manusi terbaik yang pernah ada di muka bumi ini, Nabi Muhammad saw.

a. Hadis Azl

Pertimbangan pertama yang ingin penulis kemukakan adalah hadis yang menjelaskan tentang bolehnya 'azl agar tidak terjadi kehamilan, Nabi bersabda :

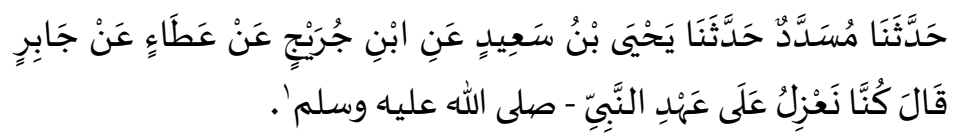

Kami melakukan 'Azlpada masa Nabi masih hidup.

Dalam riwayat Muslim, hadis tersebut dikomentari

${ }^{1}$ Abu 'Abdillah al Bukhari, Șahih Bukhärí, vol III (Kairo: Maṭba ah al Salafiah, 1400 H), 390. 
oleh Sufyan bahwa seandainya ada pelarangan, maka Alquran pasti melarangnya:

حدثنا أبو بكر بن أبي شيبة وإسحاق بن إبراهيم ( قال إسحاق أخبرنا وقال أبو بكر حدثنا سفيان) عن عمرو عن عطاء عن جابر قال كنا نعزل والقرآن ينزل زاد إسحاق قال سفيان لو كان شيئا ينهى عنه لنهانا

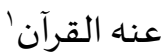

kami melakukan 'azl pada masa Alquran diturunkan. Ishāq menambahkan bahwa Sufyan berkata seandainya ada ajaran yang melarang, maka al Qur'an past akan melarang perbuatan kita. ${ }^{2}$

Kedua hadis tersebut memberikan pemahaman bahwa Rasulullah tidak melarang perbuatan 'Azl. Mayoritas Ulama' berpendapat bahwa 'azl itu diperbolehkan dengan izin dari istrinya karena istimtā' itu juga haknya isteri.

Tidak adanya pelarangan tersebut menunjukkan bahwa jumlah banyaknya anak yang akan membanggakan Nabi sebenarnya kembali kepada kondisi tiap-tiap individu. Artinya, seandainya Nabi menginginkan umatnya memiliki anak banyak tanpa batas, maka pasti beliau akan melarang perbuatan 'Azl tersebut.

b. Kritik Praksis

Pertimbangan kedua adalah kondisi masa kini. Pertimbangan

${ }^{1}$ Muslim al Hajjāj, Șaḥiḥ Muslim, Vol 1 (Riyad: Dār Ṭayyibah, 2006), 657.

2 Informasi lebih detail tentang kajin hadis 'Azl ini, silahkan baca buku karya: Yusuf al Qardhawi, Kaifa natāamal ma'a al Sunnah al Nabawiyah, 137. 
ini penting karena di kalangan masyarakat muncul sebuah pemikiran yang mempertentangkan antara perintah Nabi tersebut dengan kondisi Negara Indonesia yang menggalakkan program keluarga berencana yang disingkat dengan istilah KB dengan selogan "dua anak cukup". Menurut sumber yang penulis suguhkan, bahwa program KB tersebut digulirkan pemerintah dan disosialisakan bahkan diwajibkan bagi pegawai Negeri dan bahkan ada yang keterlaluan dalam mensosialisasikan dalam bentuk ungkapan yang ditulis dengan huruf besar di daerah Bangkalan Madura. Di daerah Bangkalan tersebut, dalam rangkan mempromosikan program KB tersebut, ditulis "banyak anak banyak masalah". ${ }^{1}$

Fakta bahwa pemerintah menerapkan program KB tersebut dan mewajibkan kepada pegawai negeri baik sipil maupun TNI tersebut memancing sebauh pertanyaan filosofis tentang mengapa Pemerintah menggalakkan program KB tersebut? Menurut hemat penulis, pertanyaan tersebut tidak cukup hanya dijawab dengan alasan untuk memperbaiki kualitas hidup, meningkatkan kesejahteraan dan menjamin kecukupan sumber daya alam bagi seluruh umat manusia.

1 Tulisan tersebut ditemukan ketika melintasi jalan di daerah Bangkalan Tahun 2012. Menurut informasi dari seorang mahasiswa STAI Taswirul Afkar yang bernama Fawaid dari Sumenep, Madura bahwa tulisan semacam itu juga ada di kabupaten Sumenep. 
Beberapa negara maju kini tengah menghadapi krisis populasi. Austria, Swedia, dan beberapa Negara Eropa Barat mengalami apa yang dinamakan dengan The Ageing of Europe. Jumlah penduduknya akan didominasi orang-orang usia lanjut. Rendahnya angka kelahiran di Negara-negara tersebut menimbulkan persoalan kurangnya generasi muda dan tenaga kerja usia produktif. Austria misalnya, pada tahun 2030 membutuhkan tenaga kerja imigran sebesar 100.000 di bidang sosial dan kesehatan.

Sebuah lembaga riset di Jepang menyatakan bahwa populasi di Jepang akan berkurang sepertiga pada tahun 2050. Dan pada tahun 2105 jumlah orang Jepang di dunia tinggal 44 juta. Total rasio kelahiran yang terus merosot (1,37 di tahun 2008), jauh dari rasio pertumbuhan penduduk yang dapat mendukung kestabilan populasi berkesinambungan $(2,1)$. Jepang bisa dikategorikan sebagai decaying country, atau Negara yang menuju pada kepunahan. Karena itu pemerintah Jepang membuat berbagai program, salah satunya tunjangan sebesar 26.000 yen (sekitar 2,6 juta) per bulan per anak agar perempuan Jepang mau punya anak ${ }^{1}$.

Kholda Naajiyah menyatakan bahwa program Keluarga Berencana (KB) yang digeber sejak 1970-an, pernah sukses besar di era Orde Baru, hingga menekan angka

${ }^{1}$ Muzamil, Dua anak Tidak Cukup, (Surabaya: Pesantren Luhur Al Husna, 2014), 102 
kelahiran sampai 2,6 anak per wanita. Berbagai penghargaan dunia disematkan atas keberhasilan ini. Namun, angka 2,6 dinilai masih belum ideal. Dengan slogan "dua anak cukup.

Menurutnya, KB di Indonesia, merupakan salah satu agenda internasional dalam mengendalikan populasi. Ini setelah Indonesia meratifikasi hasil International Conference on Population and Development (ICPD) di Kairo 1994. Salah satu agenda penting itu adalah pengendalian jumlah penduduk.

Sejak 1970-an, proyek ini terus berjalan. Program KB dikemas dengan tujuan seolah-olah mulia, yakni meningkatkan kualitas hidup dan kesejahteraan keluarga. Logikanya, dengan semakin beratnya beban ekonomi saat ini, jumlah anak yang sedikit akan lebih terjamin kesejahteraannya dibanding banyak anak.

Argumen tersebut berangkat dari Teori Malthus yang dianggap sebagai bapak kependudukan oleh Barat. Dikatakannya, pertumbuhan pangan ibarat deret hitung, sementara pertumbuhan penduduk ibarat deret ukur. Artinya, pertumbuhan penduduk jauh lebih banyak dibanding pertumbuhan pangan. Sehingga, jika pertumbuhan penduduk tidak dikendalikan maka akan terjadi ledakan penduduk di mana jumlah pangan yang ada tidak akan mencukupi untuk seluruh umat manusia.

Ketika teori menyesatkan ini diterapkan di Barat, 
dampaknya sungguh membahayakan. Problem sosial muncul, berupa rendahnya angka fertilitas dan tingginya penduduk usia tua. Negara Barat terancam kekurangan SDM usia produktif karena rendahnya angka kelahiran generasi penerus. Fenomena ini terjadi di Jerman, Italia, dan Spanyol. Bahkan di Asia terjadi di Korea dan Jepang.

Di sisi lain, karena kekurangan SDM produktif, negeri-negeri barat akhir-akhir ini diserbu imigran dari negeri-negeri Islam, khususnya Timur Tengah. Kaum imigran Muslim ini menjadi pemasok terbesar bagi tenaga kerja di sana. Kehadiran imigran dengan ajaran Islamnya, sangat mengkhawatirkan Barat. Terlebih dengan banyaknya generasi yang mereka lahirkan. Bukan tidak mungkin, 10, 20 atau 30 tahun ke depan, pemegang kendali perekonomian di Barat akan jatuh ke tangan para imigran Muslim ini. Hal itu bisa terjadi jika proses regenerasi di Barat tidak menunjukkan perbaikan.

Ini bukan masalah remeh bagi Barat, melainkan ancaman besar. Barat pun menyadari bahwa pengendalian penduduk adalah langkah keliru. Kini, mereka justru mendorong para wanita agar mau hamil dan melahirkan. Iming-iming fasilitas menggiurkan diberikan agar angka natalitas kembali menggeliat.

Sebaliknya, rekayasa pengendalian ledakan penduduk dialihkan sasarannya menuju negara-negara dunia 
ketiga (baca: Muslim). Tujuan sesungguhnya adalah: menghentikan ledakan penduduk Muslim.

Dari paparan tersebut, dapat dinyatakan bahwa Proses regenerasi adalah faktor terpenting bagi eksistensi sebuah keluarga, suku, komunitas, negara dan bahkan sebuah peradaban. Jika proses regenerasi terhenti, yang terjadi adalah hilangnya sebuah keluarga, suku, negara dan bahkan peradaban itu.

Dalam skala negara, masalah regenerasi ini menjadi sangat penting. Sebuah negara yang tidak memikirkan proses regenerasi bisa terancam punah. Spanyol misalnya, salah satu negeri yang terancam 'punah'. Tingkat kelahiran bayi termasuk yang paling rendah di dunia. Rata-rata angka kelahiran perempuan Spanyol adalah 1,12. Jika dari waktuke waktu tidak ada bayi lahir di sana, maka dalam jangka panjang penduduk negeri itu akan habis. Peradaban Spanyol pun sudah dipastikan akan lenyap. Hal itu bukanlah sesuatu yang mustahil.

Dalam konteks Indonesia, berdasarkan data statistik bahwa jumlah penduduk Indonesia selama 40 tahun dari tahun 1971-2010, mengalami peningkatan yang signifikan, yaitu 100 juta penduduk. Data tersebut menurut hemat penulis masih menunjukkan tingkat kesuburan dan kemauan penduduk Indonesia untuk memiliki anak tidak mengkhawatirkan. Namun, jika pemerintah semakin 
menggalakkan perogram KB dengan slogan "dua anak cukup" apalagi dibumbui dengan slogan "jahiliyah" yang sempat penulis baca di beberapa daerah yang bertuliskan "banyak anak banyak masalah", maka bukan tidak mungkin pertumbuhan penduduk akan mengalami kemerosotan dan pada akhirnya kita juga akan mengalami kondisi yang mengkhawatirkan seperti yang terjadi pada Jepang dan sebagian Negara Eropa.

Menurut hemat penulis, anjuran Rasulullah untuk memperbanyak keturunan mengirimkan pesan kepada kita bahwa keberlanjutan sebuah Negara sangat ditentukan oleh proses regenerasi pada negara tersebut. Dalam konteks Indonesia, disamping negara harus memikirkan regenerasi bangsa ini, Indonesia juga harus memikirkan tentang peningkatan kualitas generasi selanjutnya agar terlahir generasi emas yang dapat membawa Indonesia lebih baik dalam berbagai aspek.

Dari paparan tersebut, penulis berkesimpulan, sebagai orang Indonesia yang beragama Islam, maka hendaknya Indonesia tetap harus menerapkan program KB untuk mengontrol laju jumlah penduduk sehingga pemerintah kemungkinan kecil akan kedodoran dalam menjalankan rencana peningkatan kualitas penduduknya, tapi bukan dengan slogan "dua anak cukup", tapi diganti dengan slogan "tiga anak cukup". 
Kenapa tiga anak? Karena angka tiga dalam bahasa Arab sudah menunjukkan jumlah banyak dan itu artinya, kita sudah memenuhi kriteria untuk dibanggakan oleh Rasulullah saw. Adapun batas maksimal, maka diserahkan kepada kondisi masing-masing Individu.

Jadi yang menjadi pertimbangan penulis bukan habisnya stok makanan seperti logika yang dibangun oleh orang barat tetapi pertimbangan memperbaiki kualitas penduduk terutama pemahaman tentang hidup dan kehidupan ini. Sebagai sebuah renungan bahwa Allah menciptakan sumber kekayaan alam ini lebih dari cukup untuk seluruh penduduk dunia.

Problem itu bukan banyaknya penduduk tapi keserakahan segelintir manusia, tidak meratanya distribusi kekayaan dan pengelolaan sumber daya alam yang salah adalah sumber ketidak-adilan dan ketidaksejahteraan. Seluruh individu manusia seharusnya sejahtera, jika sumber kekayaan alam dikelola penuh amanah. Sebagaimana ketika Khalifah Umar bin Abdul Azis berkuasa, tak ada satupun umat yang berhak menerima zakat. Sungguh sebuah impian seluruh masyarakat.

Dalam perspektif fiqh, Mahmud Syaltut berpendapat bahwa Program KB yang bermaksud membatasi anak dalam jumlah tertentu dan berlaku untuk semua keluarga dalam kondisi dan situasi apapun, bertentangan dengan Syari'at 
Islam karena hikamah penciptaan manusia di dunia ini adalah untuk berkembang biak dan memanfaatkan karunia Allah yang terhampar luas. Tetapi jika program KB tersebut dimaksudkan sebagai usaha pengaturan kelahiran, atau usaha pencegahan kehamilan sementara atau untuk selamanyasehubungan dengan situasi dan kondisi tertentu-baik untuk kepentingan keluarga yang bersangkutan maupun untuk kepentingan masyarakat dan negara, tidak dilarang oleh Agama. ${ }^{1}$

c. Kajian Psikologis; Teori sibling rivalry

Pertimbangan ketiga ini bertumpu pada teori psikologi, sibling rivalry tentang kecemburuan, persaingan dan pertengkaran antara saudara laki-laki dan saudara perempuan. Hal tersebut bisa terjadi pada semua orang tua yang mempunyai dua anak atau lebih. ${ }^{2}$

Sibling rivalry terjadi jika anak merasa mulai kehilangan kasih sayang dari orang tua dan merasa bahwa saudara kandung adalah saingan dalam mendapatkan perhatian dan kasih sayang dari orang tua. ${ }^{3}$

Persaingan antar saudara yang dimaksud di sini adalah kompetisi antara saudara kandung untuk

\footnotetext{
${ }^{1}$ Mahmud Syaltut, al Fatawa (Mesir: Dar al Syuruq, 2004), 252-255.

${ }^{2}$ http://www.lusa.web.id/sibling-rivalry/ Diakses 19 Agustus 2014

${ }^{3}$ Setiawati dan Zulkaida Anita, Sibling rivalry pada anak sulung yang diasuh oleh single father (Ttp: Proseding Pesat, 2007).
} 
mendapatkan cinta kasih dan perhatian dari satu atau kedua orang tuanya, atau untuk mendapatkan pengakuan atau suatu yang lebih. ${ }^{1}$

Jarak usia yang lazim memicu munculnya sibling rivalry adalah jarak usia antara 1-3 tahun dan muncul pada usia 3-5 tahun kemudian muncul kembali pada usia 8-12 tahun, dan pada umumnya, sibling rivalry lebih sering terjadi pada anak yang berjenis kelamin sama dan khususnya perempuan.

Rasa cemburu terhadap seseorang seringkali berupa tingkah laku mengadu, mengkritik, atau bahkan berbohong. Beberapa ciri yang diperlihatkan untuk mendapatkan kasih sayang dan perhatian orangtuanya, yaitu: menunjukkan sikap agresif pada orangtua dan saudara kandungnya, perilaku yang tidak mau menurut pada orangtua, perilaku tidak mau mengalah pada saudara kandung, serta menunjukkan tingkah laku untuk mencari perhatian secara berlebihan.

Ciri khas yang sering rnuncul pada cemburu karena adanya sibling rivalry, adalah egois, suka berkelahi, memiliki kedekatan yang khusus dengan salah satu orangtua, ketakutan neurotic, mengalami gangguan tidur, kebiasaan menggigit kuku, hiperaktif, suka merusak, dan menuntut perhatian lebih banyak. Namun bisa pula sebaliknya menjadi

${ }^{1}$ http://www.lusa.web.id/sibling-rivalry/ Diakses 19 Agustus 2014 
penurut dan patuh, selalu mencari pertolongan tetapi dengan diam-diam berusaha untuk menang. Saudara kembar mungkin juga menunjukkan kekhawatiran yang berlebihan terhadap saudara lainnya yang dianggap sebagai saingannya.

Faktor-faktor yang mempengaruhi terbentuknya sibling rivalry, antara lain adalah Jumlah Saudara. Jumlah saudara kecil cenderung rnenghasilkan hubungan yang lebih banyak perselisihan daripada jumlah saudara yang besar.

Faktor yang lain adalah Pola Asuh. Hubungan antar saudara kandung tampak jauh lebih rukun dalam keluarga yang menggunakan pola asuh otoriter

Secara garis besar, ada dua faktor yang dapat memunculkan persaingan. Pertama, faktor eksternal, yaitu sikap orang tua yang salah seperti sikap membandingbandingkan satu dengan yang lain, serta adanya favoritisme (menganak emaskan salah satu anaknya). Kedua, faktor internal. Yaitu faktor dari diri anak sendiri seperti temperamen dan jumlah saudara.

Uraian tersebut, memberikan pemhaman bahwa dalam perspektif psikologi perkembangan, jumlah anak ternyata menjadi salah satu faktor yang dapat menimbulkan Sibling rivalry. Berdasarkan teori tersebut, dapat dinyatakan bahwa tiga anak itu lebih baik dibandingkan dengan dua anak karena potensi munculnya persaingan lebih kecil. Jika persaingan diantara saudara dapat diminimalisasi, maka 
pertumbuhan anak secara psikologis akan semakin baik. Dan jika pertumbuhan psikologinya lebih stabil, maka harapan untuk menjadi anak soleh dan berkualitas akan semakin besar. dan itu artinya, peluang untuk menjadi kebanggaan manusia teragung, Nabi Muhammad saw semakin terbuka lebar.

\section{PENUTUP}

Berdasarkan uraian tersebut dapat disimpulkan sebagai berikut :

1. Dengan menerapkan metode tersebut, penulis berkesimpulan bahwa hadis yang memerintahkan untuk memperbanyak keturunan berkualitas sahih dari sisi sanad dan matan. Dari sisi sanad, hadis ini memiliki lima jalur dari level sahabat sampai kolektornya. Dalam ilmu Mustalah al Hadith, hadis tersebut termasuk dalam kategori hadis ahad yang secara spesifik disebut hadis masyhur.

2. Adapun jumlah anak yang ideal adalah tiga dengan argumen a) Dalam bahasa Arab, kata banyak atau jama' merujuk pada minimal tiga. b) Untuk mempertahankan Peradaban dan kebudayaan yang sangat terkait dengan regenerasi sebuah bangsa. c) Menurut teori Sibling rivalry, Stabilitas perkembangan psikologis anak lebih baik jika jumlah anak lebih dari dua. 


\section{DAFTAR PUSTAKA}

'Asqalānī al, Ibnu Ḥajar, Tahzīb al Tahzìb. Beirut: Dār al Fikr, 1984.

Bukhāri al, Abu Abdillah, Saḥịh al Bukhāri. Kairo: Maṭba ah al Salafiah, $1400 \mathrm{H}$.

Dāud, Abū, Sunan Abī Dāud. Beirut: Dār Ibn Ḥazm, 1997.

Ghulayaini, Mustafa, Jāmi' al Durūs al 'Arabiyah. Beirut: Maktabah al 'Asriyah, 1987.

Hajjāj al, Muslim Ibn, Șahịh Muslim. Riyaḍ: Dār al Ṭayyibah, 2006

Hambal, Ahmad Ibn, Musnad Ahmad Ibn Hambal .Beirut: Muassasah al Risālah, 1997.

Ismail, M. Syuhudi, Cara Peraktis Mencari Hadis. Jakarta: Bulan Bintang, 1991.

........, Hadis Nabi Menurut Pembela, Pengingkar dan Pemalsunya. Jakarta: Gema Insani Press, 1995.

........, Hadis Nabi yang tekstual dan kontekstual. Jakarta: Bulan Bintang, 1994.

........., Metodologi Penelitian Hadis Nabi . Jakarta: Bulan Bintang, 1992.

Nasāi al, Ahmad Ibn Syuaib, Sunan al NasāI. Beirut: Dār al Ma'rifah, T.th.

Qazwaini al, Muhammad Ibn Yazīd, Sunan Ibn Mājah. Beirut: Dār al Ma'rifah, T.Th.

Qorḍawi al, Yusuf, Kaifa Nata'amāl ma'a al Sunnah al Nabawiyah. Kairo: Dār al Syurūq, 2002.

Shaltut, Mahmūd, al Fatāwa. Mesir: Dār al Shurūq, 2004. 
Sijistāni al, Sulaiman Ibn Asy'as, Sunan Abi Dāud. Beirut: Dār Ibn Ḥazm, 1997.

Soekanto, Soerjono, Sosiologi Suatu Pengantar, Jakarta: Raja Grafindo Persada, 2007.

Setiawati dan Zulkaida Anita, Sibling rivalry pada anak sulung yang diasuh oleh single father (Ttp: Proseding Pesat, 2007).

Uwaidah, Kamil Muhammad Muhammad, A'lamu al-Fuqaha' wa al-Muhaddisin: Abu Daud. Beirut: Dar al-Kutub al-Ilmiah, 1996.

Winsinck, Aj, Concordence et indices de la tradition Mussulmane, diterjemahkan oleh Muhammad Fu'ad 'Abdul Bāqi dengan judul Mu'jam al Mufahras li Alfä al Hadith al Nabawi. leiden: EJ. Brill, 1936 M.

........., Miftạh Kunūz al Sunnah. Lahore: Suhail Akademi, 1971 M.

Zainu, Muhammad Ibn Jāmil, Kaifa Nurabbi Aulādana, Tt: Tth.

Zuhdi, Masjfuk, Masail Fiqhiyah (Jakarta: PT. Gunung Agung, 1997.

http://www.bps.go.id

http://www.mui.or.id

http://www.republika.co.id/berita/nasional/umum/11/07/05/lnu a4p-prediksi-bkkbn-2011-penduduk-indonesia-241juta-jiwa

http://www.lusa.web.id/sibling-rivalry/ 